\title{
Influence of Internal Organizational Factors on E-procurement Adoption in Small and Medium-Sized Enterprises in Nyeri County Kenya
}

\author{
Peter Waweru Gitonga $^{1} \quad$ Judith Nelima Wasike $^{2} \quad$ Evans Vidija Sagwa $^{3}$ \\ 1.Candidate, Master of Business Administration, Department of Business Administration and Entrepreneurship, \\ School of Business and Management Studies, Technical University of Kenya, Nairobi Kenya \\ 2.Assistant Lecturer, Department of Management Science, School of Business and Management Studies, \\ Technical University of Kenya, Nairobi Kenya \\ 3.Senior Lecturer, Department of Business Administration and Entrepreneurship, School of Business and \\ Management Studies, Technical University of Kenya, Nairobi Kenya
}

\begin{abstract}
The researchers acknowledge the funding support from the German Academic Exchange Service (DAAD) for the research study and The Technical University of Kenya for facilitating the research study

Abstract

Small and Medium-Sized Enterprises (SMEs) are considered as major pillars of the modern market economies given that they play critical economic and social roles world over more so in developing countries like Kenya. Though E-procurement provides benefits that SMEs could gain from, some internal organizational factors have inhibited effective E-procurement adoption in SMEs. The objective of this study was to assess the influence of internal organizational factors on E-procurement adoption in Small and Medium-Sized Enterprises in Nyeri County Kenya. The study hypothesized that internal organizational factors do not have a significant influence on E-procurement adoption in Small and Medium-Sized Enterprises in Nyeri County Kenya. The study was guided by the Resource Based Theory. In the study, internal organizational factors was the independent variable and Eprocurement adoption was the dependent variable. The study used a self-administered questionnaire for data collection that was issued to 105 Small and Medium-Sized Enterprise business owners within Nyeri County. A Pilot study was conducted by administering 5 questionnaires and reliability test done by use of Cronbach alpha. Data analysis was conducted using regression and correlation analysis in order to determine the relationship between the variables. The results were presented in tables and the findings discussed. Based on the findings the study concluded that internal organizational factors like employee knowledge, size of an organization, staff retention, trust on technology and perceptions of manager, influence E-procurement adoption in Small and Medium-Sized Enterprises. The findings of this study can assist in deepening the understanding of the challenges that hinder E-procurement adoption by SMEs for managers and policy makers as well as form a body of knowledge for referencing to scholars and academicians.
\end{abstract}

Keywords: Internal organizational factors, Small and Medium-Sized Enterprises, E-procurement

DOI: $10.7176 / \mathrm{EJBM} / 12-33-04$

Publication date: November $30^{\text {th }} 2020$

\section{Introduction}

Globally, Small and Medium-Sized Enterprises (SMEs) are known to be the engines of economic growth and development as they create employment opportunities, provide goods and services, stir innovations as well as creating a competitive edge for a country (Katua, 2014). The SMEs are also considered critical in attaining the United Nations 2030 Sustainable Development Agenda Goals, such as Goal 1 - To end poverty in the world in all its forms; Goal 8 - To promote inclusive and sustainable economic growth that ensures full, productive and decent work and employment for all; Goal 9 - To create resilient infrastructure, encourage inclusive and sustainable industrialization and nurture innovation. It is out of this importance that governments consider SMEs as the centers of industrial development as a result, development strategies and policies are usually anchored on SMEs (KBA, 2016).

Small and Medium-Sized Enterprises have no universally accepted definition due to their different nature hence their definition can be different from sector to sector depending on the economy and the time span considered (KBA, 2016; Miller \& Nyauncho, 2014; Katua, 2014). Generally, SMEs definition is based on three areas; number of employees; annual turnover and the asset level of the firm which can be formerly registered as emphasized by the Kenya National Small Business Act and Micro and Small Enterprises Act (2012). Small and Medium-Sized Enterprises play critical economic and social roles especially in third world countries such as Kenya (ITC, 2019). Studies have revealed that SMEs form a high population of business in almost all the third world countries (Katua, 2014). According to Kenya National Bureau of Statistics (2017) SMEs comprise about 98\% of all the Kenyan enterprises, they employ more than $80 \%$ of Kenya's employees who directly derive their daily income from the SMEs and they are estimated to have contributed 34\% of Kenya's Gross Domestic Product (GDP) 
in 2016. Small and Medium-Sized Enterprises even though generally informal, are the engines of job creation where they generate $80 \%$ of new jobs each year (ITC, 2019). According to KBA (2016) based on a 2014 survey $80 \%$ of the 800,000 jobs created in 2014 came from informal sector which is dominated by the SMEs.

Small and Medium-Sized Enterprises are found and support all sectors of the economy such as retail, trading, manufacturing, and service industry, and significantly contribute to job creation, industrialization, economic empowerment and inclusion, in line with the Kenya Vision 2030 blue print that recognizes the significant roles of SMEs (Mukulungui, 2016; ITC, 2019 ). The Kenyan Government's Third Medium-Term Plan 2018-2022; Towards Achieving Kenya Vision 2030, distinguishes the SME segment as a key area for development. All these links well with the United Nation's 2030 Agenda for Sustainable Development which implores the international community to promote the formalization and advancement of Micro, Small and Medium-Sized Enterprises (ITC, 2019).

The definition of SMEs in Kenya is generally based on size, number of employees, annual sales turnover and their capital base according to the SME Act 2012. The Act however does not explicitly give a definition of a Small and Medium-Sized Enterprise. Generally an SME can be defined as an enterprise that is formally registered, with an annual turnover of Kenya Shillings 8 million to Kenya shillings 100 million, has a capital base of Kenya shillings 5 million and above and a workforce of 10 to 150 employees.

The Kenyan Vision 2030, which is a long term development blue print, recognizes SMEs as key stakeholders in achieving a transformative, an industrial and high middle-income country. Small and Medium-Sized Enterprises have also been recognized as the central enablers towards achieving the 'Big Four' which is Kenyan government transformative agenda where SMEs are considered as the 'bedrock' of manufacturing under the manufacturing pillar. Therefore, policies and business reforms that will involve coming up with trade support ecosystems and capacity building at the firm level are expected to help Kenyan SMEs to be more competitive - nationally, regionally and worldwide, (ITC, 2019).

The internal organizational factors refer to the operational enablers and inhibitors which are majorly descriptive and directly relate to the accessibility and utilization of internal resources at the disposal of an organization (Mukulungui, 2016). The size of an organization, which generally is the indicator of operational resources available to a business, is positively and highly related to the adoption of e-procurement, (Manuel \& Duarte, 2015). The structure, trainings and knowledge of staff within an organization plays a key role in determining the adoption of E-procurement (Arasa, 2015). Directors or owners and employees who have a higher level of education are more likely to adopt new innovations and technologies while lack of knowledge has been identified as the highest barrier to adoption of E-procurement and Information Technology among SMEs (Oliveira $\&$ Martins, 2010). The adoption of E-procurement is also strongly depended on the commitment of the senior management in supporting the systems who must commit financial resources and managerial skills to steer the organization towards adoption of E-procurement technologies (Mgidlana, 2013).

Procurement can be defined as the process of identifying, assessing, purchasing of works, goods and services. According to the Public Procurement and Disposal Act, (2015), procurement refers to "the acquisition by purchase, rental, lease, hire purchase, license, tenancy, franchise, or by any other contractual means of any type of works, assets, services or goods including livestock or any combination and includes advisory, planning and processing in the supply chain system." Procurement starts with the identification of a need by a user and ends with the delivery of the material, works or services required and generally has four phases: requirement analysis; negotiation stage; payment phase and contract management phase. The main aim of procurement is to get the right product or service, at the right place, at the right time, at the right price in the most efficient manner possible (Fernandes \& Vieira, 2015).

Procurement has undergone various reforms in the previous years where technology has been incorporated in the various stages or even the entire process as whole. When procurement is carried out with the aid of Information Communication Technology (ICT), it is then referred to as E-procurement (Arasa, 2015). It refers to the use of electronic ways through internet for fulfillment of the procurement activities e.g. identification of organizational needs, payment processing, and contract management. E-procurement comprise of business to business, business to customers and customer to customer as well as the intra-organizational activities that aid them. Supply-side activities such as electronic procurement (E-procurement) have been identified as a key area where Information Systems (IS)-enabled innovations are likely to yield significant benefits for organizations.

Many firms are adopting E-procurement because of its advantages such as expanding markets, improving customer experience, cost reduction and enhancing efficiency and productivity (Nawi, et al., 2016). E-procurement gives the ability of increasing efficiency of payments systems and growing access to formal financial services by organizations which presently lack it. Similarly, it could make the service industry such as banks and SMEs more convenient and cheaper to their clients (KBA, 2016). The implications of adoption of E-procurement are that technology can enhance operations of SMEs including those in Nyeri County. The SMEs can realize their goals such as enhanced basic infrastructure for effective service delivery and promotion of shared economic growth and job creation, which are in line with the Nyeri County Integrated Development Plan 2018-2022. 


\subsection{Research Problem}

Though Small and Medium-Sized Enterprises play a critical role in the global economy, regional economy and national economy the advances in Information and Communication Technology, which lead to innovation of Eprocurement, largely acceptance by large organization, has not seen the same level of adoption among SMEs (Kiveu \& Ofafa, 2013). Organizations that fail to provide quality services are likely to experience drawbacks such as bad reputation due to the fact that most organizations have turned to ICT to provide competitive and quality services. The adoption of E-procurement is deemed to be a way of strengthening organizations to compete on a global scale, with more effectiveness, proximity to the customer and service provision links (Nawi, 2016). It is important that SMEs take into account ICT as a critical approach in business to grasp high ground from the markets. Moreover, ICT is a benefit to SMEs which may aid them to acquire information bearing in mind that the actual objective is to update their strength (Adeyeye, 2016). In the contemporary society, the world has to a great extent been affected by ICT particularly in procurement. Organizations are gradually transforming their businesses, work processes and trade. They are also utilizing competitive strategies to win buyers and retaining quality suppliers. Many procurement departments are aspiring to provide quality and competitive products that reflect the value for money by implementing E-procurement in an organizations (Anuar, 2015).

Various studies such as (Mukulungui, 2016; Arasa, 2015), have noted that government policies and regulations are factors that can hinder adoption of E-procurement by SMEs. These studies have not incorporated internal organizational factors in the research variables either as an independent variable. These studies have omitted internal organizational factors as a critical factor that can spell doom or success for the SMEs. The current study incorporated internal organizational factors as an independent variable. Most studies carried out on challenges of E-procurement adoption in Kenyan context are oriented towards public procurement and government agencies and little attention has been paid towards SMEs (Mambo \& Ombui, 2015; Osir, 2016; Amemba et al, 2013). This made the researchers to develop some keen interest on this area of study. Lack of abundant research and findings has resulted to failure by individuals to properly understand issues such as the internal organizational factors and how these factors may affect E-procurement adoption in organizations, especially SMEs. It is against this background that this study attempted to assess the influence of internal organizational factors on Eprocurement adoption in Small and Medium-Sized Enterprises in Nyeri County, Kenya.

\subsection{Objective of the Study}

The objective of the study was to assess the influence of internal organizational factors on E-procurement adoption by Small and Medium-Sized Enterprises in Nyeri County, Kenya.

\subsection{Research Question}

The research study set out to answer the question: Do internal organizational factors have an influence on Eprocurement adoption in Small and Medium-Sized Enterprises in Nyeri Country, Kenya?

\subsection{Value of the Research Study}

The findings from this study are of great importance to SMEs in Nyeri County and other organizations. The findings are anticipated to deepen the understanding of internal organizational factors that hinder E-procurement adoption by SMEs within Nyeri County among other places. The business entities will also benefit from the research since they will be made aware of internal organizational barriers that may be encountered when initiating E-procurement and how to avoid them.

The study is expected to be of significance to academicians, policy makers and managers in the field of procurement and supply chain management. The findings from the study are expected to form a body of knowledge from where reference can be made for contribution to policy formulation, implementation and review in SMEs statutory bodies and other organizations.

\section{Literature Review}

\subsection{Theoretical Foundation of the Research Study}

This study was guided by the Resource Based Theory. According to this theory, firms rely on their internal resources, both tangible and intangible to develop strategies that aim at improving their business performance as well as building their competitive advantage (Smadi \& Ababneh, 2018). The Resource Based Theory further suggests that for an organization to achieve excellence and obtain external opportunities, it must exploit the internal capabilities first (Jensen \& Clausen, 2017).

In this study, E-procurement is regarded as a method that ensures available resources are optimally utilized so as to enhance efficiency and effectiveness in the procurement process hence creating a competitive advantage for the SMEs. The competitive advantage ensures that there is better lead time, cost saving, and customer satisfaction. When E-procurement is adopted, there is better coordination and utilization of procurement resources which leads to seamless procurement operations which can in return, affect the adoption of e-procurement by firms 
(Laryea and Ibem, 2014).

\subsection{Internal Organizational Factors and E-procurement}

Mukulungi (2016), assessed the barriers of E-procurement adoption by SMEs in Machakos County. The study found out that the barriers to adoption of E-procurement consisted of technological barriers such as (lack of sufficient assessment of Enterprise Resource Planning (ERP) systems before installations, insufficient IT infrastructure, lack of technical and competent expertise); organizational barriers (i.e. lack of IT knowledge by management and employees, size of the firm and poor staff retention) and environmental barriers (i.e. the market segment and scope of the SMEs, high cost of implementation and acquisition and management perception of Eprocurement). The study adopted a descriptive research design and issued a self-administered questionnaire as a means of data collection.

Small and Medium-Sized Enterprises are the drivers of economies in the world. This is as a result of their efforts in making business innovations and promoting territorial growth (Shemi, 2012). The improved ICT penetration has brought significant changes in the way business is being conducted in the developed and developing countries. Globalization and accessibility of international markets has been on an all-time high and SMEs are enhancing their capacities to tap into the new globalization frontier. Governments are pushing SMEs towards modernization by funding programs and developing policies that favor them (KNBS, 2018; Republic of Kenya, 2007).

In a study conducted by Shemi (2012 that examined the factors that impact web business adoption by SMEs in the developing country setting of Botswana, the study found out that the internet business selection by the selected SMEs in the study was affected by the nearby business environment. There was little online support for business and that the role of the government in empowering SMEs was limited.

\section{Methodology}

\subsection{Research Design}

Research design refers to the preparations of precedents for gathering and examination of data in a way that aims to bring together relevance and purpose of the research in an economical manner. It is a conceptual structure upon which a research is conducted by providing the blue prints of data collection, measurement and examination (Sekaran \& Bougie., 2016). The study used descriptive research design in conducting the research since this design is concerned with describing the features of a specific individual or a group. It is concerned with the particular predictions, combined with descriptions of facts and characteristics in relation to individuals, group or situations. This design also ensures extensiveness of data and accurate descriptive examination and characteristics of the sample which can be used to make inferences of the population (Astalin, 2013).

\subsection{Population of the Study}

Population generally refers to a group of individuals, activities or objects with common recognizable features from which a sample can be drawn. Targeted population therefore refers to a specific group of individuals to which the researcher is interested in to generate conclusions (Osir, 2016). The study targeted SMEs operating within Nyeri town and its immediate environments in Nyeri County, Kenya. According to Nyeri County Licensing Department (2018), there are five hundred and twenty one (521) registered SMEs within Nyeri town and its immediate environments in Nyeri County, Kenya. The type of businesses registered are distributed approximately as large traders, shops, retail or store 405; medium workshop/service repair 54; small industrial plant up to fifteen (15) employees 34; and medium financial services six to twenty five employees (6-25 employees) approximately twenty eight employees 28 as depicted on Table 1.

Table 1: Classification and distribution of SME's in Nyeri Town

\begin{tabular}{|l|c|}
\hline Type of Target Business & Approximate Number Registered \\
\hline Large Traders, Shops, Retail or Store & 405 \\
\hline Medium Workshop/Service Repair & 54 \\
\hline Small Industrial Plant up to 15 Employees & 34 \\
\hline Medium Financial Services 6-25 Employees & 28 \\
\hline Total & 521 \\
\hline
\end{tabular}

Source: Department of Licensing Nyeri County Government (2018)

\subsection{Sample Design and Sampling Procedure}

A sample is a portion or a part of the research population chosen to take part in a study as a representative of the research study population. Sample design refers to the methods or procedures that a researcher adopts in choosing items during sampling. It is a definite plan for obtaining a sample from a given population which may at times 
give the number of items to be included in the sample, that is, the size of the sample (Sekaran \& Bougie, 2016)= The researchers adopted stratified random sampling with proportional allocations to obtain a sample of the population. This was as a result of a large study population, time and financial constraint on the part of the researchers. The method chosen was considered appropriate given that all the existing subgroups were represented and it was applicable. Each targeted business classification formed strata and samples were drawn from each stratum by random sampling to ensure that each item in the population had an equal chance of being picked and included in the sample.

Table 2 depicts how the study sample was chosen from the stratum. Mugenda \& Mugenda (2003), states that in descriptive studies, $10 \%-40 \%$ of the population chosen as a sample is sufficient if the sample size is large (exceeding a sample size of 30 respondents) hence the current study, $20 \%$ of the population was used for sampling purposes. The study sample was calculated and supported by the formulae as used by Nyakundi (2018) and Omwenga \& Iravo (2015)

$\mathrm{S}=(\mathrm{N}) / \mathrm{X}$

Where;

$\mathrm{n}=$ required sample size

$\mathrm{N}=$ given population size

$\mathrm{X}=$ given degree value of chosen population



Sample size was 105 distributed as indicated in Table 2.

Table 2: Sample size determination and distribution

\begin{tabular}{|l|c|c|c|}
\hline Type of Target Business & Number Registered & $\%$ & Sampled \\
\hline Large Traders, Shops, Retails & 405 & 20 & 81 \\
\hline Medium workshop/Service/Repair & 54 & 20 & 11 \\
\hline Small Industrial Plant up to 15 Employees & 34 & 20 & 7 \\
\hline Medium Financial Services 6-25 Employees & 28 & 20 & 6 \\
\hline Total & 521 & & 105 \\
\hline
\end{tabular}

Survey Data: 2020

\subsection{Data Collection}

Data collection involves collection of information from all available sources by use of data collection instruments. The researchers sought authority from the Technical University of Kenya before venturing into data collection. The researchers adopted a descriptive survey design which involves administering questionnaires as the major mode of data collection for the sample selected (Wachinga, 2019).

This descriptive survey design was considered appropriate since the researchers intended to use descriptive statistics to analyze the collected data on tables and through discussions. The questionnaire as a tool of data collection was distributed personally by one researcher and a research assistant through the drop and pick approach to the respondent's work place to enable gathering of primary data.

\subsection{Pilot Study}

A pilot study was conducted before the actual study was done. The pilot study provided the researchers with an opportunity to test and identify the shortcomings that could have hindered gathering of meaningful data. During the pilot study, the researchers assess the effectiveness of the instrument of data collection that is expected to be employed, this provides a chance to detect and remedy potential problems on the data collection instrument lie a questionnaire (Wasike, Sagwa \& Sakwa, 2018).

The pilot study was done through the administration of 5 survey questionnaires where the feedback was collected and the questionnaires analyzed before the final version of the questionnaire was distributed. This is in line with Wachinga, (2019) who asserts that a pilot study is usually conducted to test the validity and reliability of the questionnaires in gathering the data required for purposes of the study).

\subsection{Tests of Validity}

Sekaran \& Bougie., (2016) aver that validity is the degree to which results obtained from data analysis are an actual representation of the phenomenon studied. Validity exists in two types; content and construct validity. By 
reviewing the works of other researchers, construct validity has been safeguarded in the current research. The introduction of unbiased questions on the data collection instrument ensured that there was content validity.

Overall validity was achieved by carrying out a pre-test on the questionnaire so that questions that were impolite and vague were detected and adjusted appropriately. The research study was also validated through panels by faculty in the School of Business and Management Studies at the Technical University of Kenya.

\subsection{Tests of Reliability}

According to Wachinga (2019), reliability refers to a measure of the degree to which research instruments yield consistent results. Sekaran \& Bougie., (2016) posit that internal consistency of a set of measurement items refers to the degree to which the items are homogeneous and can be estimated using a reliability coefficient such as Cronbach's Alpha. Cronbach's Alpha correlates each item with each other item, and the total score.

When the Cronbach's alpha coefficient is closer to 1, the internal consistency reliability is deemed to be higher. Therefore, for this study, a value of 0.7 and above of Cronbach Alpha was deemed satisfactory and the research questionnaire considered reliable.

\subsection{Data Analysis and Presentation}

Once the data was collected it was checked and processed. The data was made ready for statistical analysis by conducting validation tests and checking for clearness, legibility, relevance and suitability. The quantitative data collected was analyzed by use of descriptive and inferential statistics.

Descriptive data analysis consisted of percentages, frequencies, means and standard deviations while inferential data analysis tools used consisted of regressions analysis. The results of analysis of quantitative data was presented by use of charts and tables while qualitative data obtained from open-ended questionnaires was categorized under similar themes and then presented in narrative forms.

\subsection{Ethical Considerations}

Before embarking on data collection, the researchers and research assistant requested for permission from the Technical University of Kenya. The respondents were also informed that participation in the survey was voluntary and they had the option of not participating or withdrawing from the study at any point.

The respondents were asked to honestly respond to the questions and were assured that all information that they provided would be treated as confidential and the results obtained from the study will be used solely for academic purposes only.

\section{Findings and Discussion \\ 4.1 Response Rate}

Questionnaires were distributed to 105 respondents as per the sample of the study. Out of the 105 questionnaires, 53 were collected form the respondents representing a response rate of 51\%. Aft + er checking the questionnaires they were all found to be suitable for analysis. In earlier studies like Al-Zu'bi et al. (2015) in a study on collaboration with suppliers and lead users in new product development and open innovation: Empirical evidence from Jordanian Companies, paid visits personally to all companies in order to ensure a high participation rate in data collection. The study yielded a response rate of $52.8 \%$.

In another related study that was carried out by Oliveira et al. (2011) on supply chain process collaboration and Internet utilization: An international perspective of business-to-business relationships in Brazil, response rate realized was $21.4 \%$. While a study by Blome et al. (2014) on supply chain collaboration and sustainability: a profile deviation analysis yielded a response rate of $18.5 \%$. The response rate of the current study could be attributed to the fact that data was being collected in the months of August and September 2020. Around that time, there was implementation of guidelines and health protocols put in place by the World Health Organization (WHO) and the Ministry of Health in Kenya to combat the Covid 19 health pandemic. These controls limited operational hours that could have seen the study realize a higher response rate.

\subsection{Bio-Data Characteristics}

The study sought to establish the bio-data characteristics of the respondents and their SMEs hence the respondents were requested to indicate their age distribution, gender, highest level of education, years their SMEs had been in operation, the current number of employees and category of the SME's capital base in Kenya shillings. The age bracket of an individual may have a bearing on the ability to use emerging technologies like E-procurement. The level of education that an individual has can influence their appreciation of technology, this is consistent with other studies (Oliveira \& Martins, 2010). The gender diversity in an SME may have an influence on internal activities. The years that an organization has been in operation is a crucial aspect that may impact on the internal infrastructure of an entity.

The current number of employees determines the size of an SME, this may contribute a diversity of skills 
among the workers including human resource capacity to adopt and adapt new technologies like E-procurement. Organizational capital base can have a bearing on turnover, need and ability to invest in technology for operational competitiveness. The respondent's bio data characteristics that captured respondent's age, gender, education level, years of operation, the current number of employees, and organizational capital base is presented in Table 3

Table 3: Bio Data Characteristics

\begin{tabular}{|c|c|c|c|}
\hline Bio Data Characteristics & Category & Frequency & Percent \\
\hline \multirow[t]{6}{*}{ Age } & $18-25$ & 22 & 42 \\
\hline & $26-35$ & 20 & 38 \\
\hline & $36-45$ & 5 & 9 \\
\hline & $46-55$ & 5 & 9 \\
\hline & Over 55 & 1 & 2 \\
\hline & Total & 53 & 100 \\
\hline \multirow[t]{3}{*}{ Gender } & Male & 28 & 53 \\
\hline & Female & 25 & 47 \\
\hline & Total & 53 & 100 \\
\hline \multirow[t]{5}{*}{ Education Level } & Certificate & 15 & 28 \\
\hline & Diploma & 23 & 44 \\
\hline & Degree & 14 & 25 \\
\hline & Postgraduate & 1 & 2 \\
\hline & Total & 53 & 100 \\
\hline \multirow[t]{5}{*}{ Years of Operation } & Less than 5 & 34 & 64 \\
\hline & $5-10$ & 8 & 15 \\
\hline & $11-15$ & 4 & 8 \\
\hline & Over 15 & 7 & 13 \\
\hline & Total & 53 & 100 \\
\hline \multirow[t]{6}{*}{ Current Employees } & $0-10$ & 43 & 81 \\
\hline & $11-20$ & 5 & 9 \\
\hline & $21-30$ & 1 & 2 \\
\hline & $31-40$ & 2 & 4 \\
\hline & Above 40 & 2 & 4 \\
\hline & Total & 53 & 100 \\
\hline \multirow[t]{4}{*}{ Organizational Capital Base in Kenya Shillings } & Below 500,000 & 25 & 47 \\
\hline & $500,000-5,000,000$ & 22 & 42 \\
\hline & Over $5,000,000$ & 6 & 11 \\
\hline & Total & 53 & 100 \\
\hline
\end{tabular}

\section{Survey Data: 2020}

\subsection{Descriptive Statistics}

\subsubsection{Extent of Internal Organizational Factors Influence on E-procurement Adoption in SMEs}

The respondents were requested to indicate the extent to which they agreed with the statements on factors influencing e-procurement adoption by SMEs. The respondents were required to tick the appropriate box on a five likert type scale where: $1=$ Not at all, $2=$ Less extent, $3=$ Moderate extent, $4=$ Large extent, while $5=$ Very large extent. The findings are indicated in Table 4. 
Table 4: Extent of Influence of Internal Organization Factors on E-procurement Adoption in Small and Medium-Sized Enterprises

\begin{tabular}{|c|c|c|c|c|c|c|}
\hline Statement & 1 & 2 & 3 & 4 & 5 & Mean \\
\hline Employee knowledge influences E-procurement adoption & $\begin{array}{c}1 \\
(2)\end{array}$ & $\begin{array}{l}3 \\
(6)\end{array}$ & $\begin{array}{c}7 \\
(13)\end{array}$ & $\begin{array}{l}13 \\
(24)\end{array}$ & $\begin{array}{c}29 \\
(55)\end{array}$ & 4.24 \\
\hline $\begin{array}{l}\text { Organization size and structure influence E-procurement } \\
\text { adoption }\end{array}$ & $\begin{array}{c}5 \\
(9)\end{array}$ & $\begin{array}{c}7 \\
(13)\end{array}$ & $\begin{array}{l}14 \\
(26)\end{array}$ & $\begin{array}{c}9 \\
(17)\end{array}$ & $\begin{array}{c}18 \\
(35)\end{array}$ & 3.52 \\
\hline Low staff retention rates influence e-procurement adoption & $\begin{array}{c}5 \\
(9)\end{array}$ & $\begin{array}{c}12 \\
(23)\end{array}$ & $\begin{array}{c}12 \\
(23)\end{array}$ & $\begin{array}{l}13 \\
(24)\end{array}$ & $\begin{array}{l}11 \\
(21)\end{array}$ & 3.15 \\
\hline $\begin{array}{l}\text { Management of IT knowledge and functions influence E- } \\
\text { procurement adoption }\end{array}$ & $\begin{array}{c}2 \\
(4)\end{array}$ & $\begin{array}{c}6 \\
(11)\end{array}$ & $\begin{array}{c}19 \\
(36)\end{array}$ & $\begin{array}{c}16 \\
(30)\end{array}$ & $\begin{array}{c}10 \\
(19)\end{array}$ & 3.49 \\
\hline $\begin{array}{l}\text { Poor organization structures and bureaucracy affect E- } \\
\text { procurement adoption }\end{array}$ & $\begin{array}{c}3 \\
(6) \\
\end{array}$ & $\begin{array}{c}5 \\
(9) \\
\end{array}$ & $\begin{array}{c}9 \\
(17) \\
\end{array}$ & $\begin{array}{c}18 \\
(34) \\
\end{array}$ & $\begin{array}{c}18 \\
(34) \\
\end{array}$ & 3.81 \\
\hline $\begin{array}{l}\text { Resistance to change and uptake of IT innovations is a } \\
\text { challenge to E-procurement adoption }\end{array}$ & $\begin{array}{c}5 \\
(9) \\
\end{array}$ & $\begin{array}{c}7 \\
(13) \\
\end{array}$ & $\begin{array}{c}9 \\
17 \\
\end{array}$ & $\begin{array}{c}12 \\
(23) \\
\end{array}$ & $\begin{array}{c}19 \\
(36) \\
\end{array}$ & 3.58 \\
\hline $\begin{array}{l}\text { E-procurement adoption is affected by low levels of trust on } \\
\text { technology reliance in business activities }\end{array}$ & $\begin{array}{c}2 \\
(4)\end{array}$ & $\begin{array}{l}11 \\
(21)\end{array}$ & $\begin{array}{c}17 \\
(32)\end{array}$ & $\begin{array}{c}8 \\
(15)\end{array}$ & $\begin{array}{c}15 \\
(28) \\
\end{array}$ & 3.43 \\
\hline $\begin{array}{l}\text { Perceptions of the manager on E-procurement affects its } \\
\text { adoption }\end{array}$ & $\begin{array}{c}1 \\
(2)\end{array}$ & $\begin{array}{c}9 \\
(17)\end{array}$ & $\begin{array}{c}14 \\
(26)\end{array}$ & $\begin{array}{c}10 \\
(19)\end{array}$ & $\begin{array}{c}19 \\
(36)\end{array}$ & 3.70 \\
\hline
\end{tabular}

Survey Data: 2020

From the findings regarding the extent to which the respondents agreed with the statements on the influence of internal organization factors on E-procurement adoption in SMEs, the statement that had the highest mean was 'Employee knowledge influences E-procurement adoption' (mean=4.24). This was followed by the statement 'Poor organization structures and bureaucracy affect e-procurement adoption' (mean=3.81). The next statement was 'Perceptions of the manager on e-procurement affects its adoption' (mean=3.70). The next statement was 'Resistance to change and uptake of IT innovations is a challenge to e-procurement adoption' (mean=3.58). The statement that followed was 'Organization size and structure influence e-procurement adoption' (mean=3.52). The subsequent statement was 'Management of IT knowledge and functions influence e-procurement adoption (mean=3.49). The statement that followed was 'E-procurement adoption is affected by low levels of trust on technology reliance in business activities' (mean=3.43). The statement that had the lowest mean was 'Low staff retention rates influence E-procurement adoption' (mean=3.15). These findings which range from a moderate to a large extent illustrate that internal organization factors like employee knowledge, size of an organization, staff retention, and trust on technology and perceptions of manager influence E-procurement adoption in Small and Medium-Sized Enterprises.

These findings are corroborated with studies conducted by on competitive advantage by Smadi \& Ababneh, (2018) and also The Resource Based Theory which suggests that for an organization to achieve excellence and obtain external opportunities, it must exploit the internal capabilities first (Jensen \& Clausen, 2017).

\subsubsection{Extent of E-procurement Adoption by Small and Medium-Sized Enterprises}

The respondents were requested to indicate the extent to which they agreed with the statements on the extent of Eprocurement adoption by SMEs. The respondents were required to tick the appropriate box on a five likert type scale where: $1=$ Not at all, $2=$ Less extent, $3=$ Moderate extent, $4=$ Large extent, while $5=$ Very large extent. The findings are indicated in Table 5.

Table 5: Extent of E-procurement Adoption in Small and Medium-Sized Enterprises

\begin{tabular}{|l|c|c|c|c|c|c|}
\hline Statements & 1 & 2 & 3 & 4 & 5 & Mean \\
\hline $\begin{array}{l}\text { E-procurement adoption leads to lower costs as a result of } \\
\text { reduced staff costs and improved revenues }\end{array}$ & $\begin{array}{c}10 \\
(19)\end{array}$ & $\begin{array}{c}6 \\
(12)\end{array}$ & $\begin{array}{c}9 \\
(17)\end{array}$ & $\begin{array}{c}14 \\
(26)\end{array}$ & $\begin{array}{c}14 \\
(26)\end{array}$ & 3.30 \\
\hline $\begin{array}{l}\text { E-procurement adoption has led to improved quality } \\
\text { service delivery }\end{array}$ & $\begin{array}{c}6 \\
(4)\end{array}$ & $\begin{array}{c}13 \\
(12)\end{array}$ & $\begin{array}{c}19 \\
(24)\end{array}$ & $\begin{array}{c}13 \\
(36)\end{array}$ & 3.66 \\
\hline $\begin{array}{l}\text { There is reduction in time due to improved internal } \\
\text { workflow associated with adoption of e-procurement }\end{array}$ & $\begin{array}{c}3 \\
(6)\end{array}$ & $\begin{array}{c}5 \\
(9)\end{array}$ & $\begin{array}{c}12 \\
(23)\end{array}$ & $\begin{array}{c}16 \\
(30)\end{array}$ & $\begin{array}{c}17 \\
(32)\end{array}$ & 3.74 \\
\hline $\begin{array}{l}\text { There is improved procurement efficiency due to E- } \\
\text { procurement adoption }\end{array}$ & $\begin{array}{c}0 \\
(0)\end{array}$ & $\begin{array}{c}12 \\
(9)\end{array}$ & $\begin{array}{c}16 \\
(23)\end{array}$ & $\begin{array}{c}20 \\
(30)\end{array}$ & 3.96 \\
\hline
\end{tabular}

\section{Survey Data: 2020}

Based on the findings the statement with the highest mean that the respondents agreed with was that 'there is improved procurement efficiency due to e-procurement adoption' (mean $=3.96$ ). This followed with the statement 'there is reduction in time due to improved internal workflow associated with adoption of e-procurement $($ mean=3.74). The next statement that followed was 'E-procurement adoption has led to improved quality service delivery (mean=3.66). the statement that had the lowest mean was 'E-procurement adoption leads to lower costs 
as a result of reduced staff costs and improved revenues (mean=3.30). These findings depict that from a moderate to a large extent, small and medium-sized enterprises that adopt E-procurement realize improved efficiency in their operations. These findings are supported by studies conducted by Mukulungi (2016), and Shemi, 2012.

\section{Conclusion and Recommendations}

5.1 Conclusion

In view of the findings the study established that there was support that internal organization factors influence Eprocurement adoption by SME's in Nyeri county Kenya. The study concludes that internal organizational factors internal organization factors like employee knowledge, size of an organization, staff retention, trust on technology and perceptions of manager influence E-procurement adoption in Small and Medium-Sized Enterprises.

\subsection{Recommendations}

The study recommends that organizations that intend to operate efficiently have make deliberate measures to enhance their internal organizational factors like employee knowledge, optimum size, perceptions of mangers regarding information technology, employee retention and building trust regarding technology so that they effectively adopt E-procurement in their operations and be competitive in their areas of operation.

\section{References}

Adeyeye (2016). 'Challenges to SME growth in Kenya.' How We Made It in Africa. Retrieved from https://www.howwemadeitinafrica.com/challenges-sme-growth-kenya/57022/

Al-Zu'bi, Z.M.F., Tarawneh, E., Abdallah, A. B., \& Fidawi, M. (2015). Investigating supply chain integration effects on environmental performance in the Jordanian food industry. American Journal of Operations Research, 5(4), 247-257.

Amemba, C. S., Nyaboke, P. G., Osoro, A., \& Mburu, N. (2013). Challenges Affecting Public Procurement Performance Process in Kenya. International Journal of Research in Management, Issue, 3

Anuar, F. (2015). To Determine the Procurement Performance on E-Procurement Technology Usage and Procurement Practices on an Organization. SSRN Electronic Journal. doi: 10.2139/ssrn.2698540

Astalin, P. K. (2013). Qualitative Research Designs: A Conceptual Framework, 2(1), 118-124. Creswell, J. W. (2014). Research Design.

Arasa, R. M. (2015). Antecedents to successful adoption of e-procurement in textile and apparel firms in Kenya.

Blome, C., Paulrah, A. \& Schuetz, K. (2014). Supply chain collaboration and sustainability: a profile deviation analysis. International Journal of Operations and Production Management, 35(5), 639-663.

Fernandes, T., \& Vieira, V. (2015). Public e-procurement impacts in small-and medium-enterprises. International Journal of Procurement Management, 8(5), 587-607.

International Trade Centre (2019). Promoting SME competitiveness in Kenya: Targeted solutions for inclusive growth. ITC, Geneva

Jensen, A., \& Clausen, T. H. (2017). Origins and emergence of exploration and exploitation capabilities in new technology-based firms. Technological Forecasting and Social Change, 120, 163-175

Katua, D.T. (2014). The Role of SMEs in Employment Creation and Economic Growth in Selected Countries, International Journal of Education and Research, Vol 2, No.12

Kenya Bankers Association Centre for Research on Financial Markets and Policy. (2016). Financing Small and Medium Enterprise: The Reconciliation of Borrower-Lender Expectations. Nairobi, Kenya: Kenya Bankers Association.

Kenya National Bureau of Statistics (2017) Economic Survey, Kenya National Bureau of Statistics, Nairobi Kenya Kenya National Treasury and Planning. 2018. "Third Medium Term Plan 2018 - 2022: Transforming Lives Advancing Socio-Economic Development through the 'Big Four." Nairobi, Kenya: Kenya National Treasury and Planning. http:// vision2030.go.ke/inc/uploads/2019/01/THIRD-MEDIUM-TERM-PLAN-20182022.pdf

Kiveu, M., \& Ofafa, G. (2013). Enhancing market access in Kenyan SMEs using ICT. Global Business and Economics Research Journal, 2(9), 29-46.

Laryea, S. and Ibem, E.O. (2014) Patterns of Technological Innovation in the use of e- Procurement in Construction. Journal of Information Technology in Construction, 19, p.104-125

Mambo, P. N., Ombui, K., \& Kagiri, A. (2015). Factors influencing implementation of e-procurement in the national government: a case of the ministry of interior and co-ordination of national government. Strategic Journal of Business \& Change Management, 2(1), 12-25

Manuel, B., \& Duarte, A. (2015). Determinants of B2B E-purchasing adoption by SMEs.

Mgidlana, L. M. (2013). Factors affecting the adoption of e-procurement technologies from the supplier perspective (Doctoral dissertation, University of Pretoria).

Miller, M.M and Nyauncho, E (2014). State of Practice of SME banking. Growth Cap/FSD Kenya. 
Mugenda, O., \& Mugenda, A. G. (2003). Research methods: Quantitative and Qualitative methods. Revised in Nairobi.

Mukulungui, A. (2016). Barriers to E-procurement Adoption by Small and Medium Enterprises in Machakos County (Unpublished Doctoral dissertation, University of Nairobi).

Nawi, M. N., Roslan, S., Salleh, N. A., Zulhumadi, F., \& Harun, A. N. (2016). The benefits and challenges of Eprocurement implementation: A case study of Malaysian Company. International Journal of Economics and Financial Issues, 6(S7), 329-332.

Nyakundi, M. G. (2018). Procurement Best Practices and Procurement Performance of SMEs in Nairobi County (Doctoral dissertation, university of Nairobi).

Nyeri County Integrated Development Plan 2018-2022; towards a competitive and prosperous county; February 2018.

Oliveira, M., McCormack, K., Ladeira, M., Trkm, P., \& Bergh, J. (2011). Supply chain process collaboration and internet utilization: An international perspective of business-to-business relationships. Economic and Business Review, 13(4), 203-226.

Oliveira, T., \& Martins, M. F. (2010). Information technology adoption models at firm level: review of literature. In European Conference on Information Management and Evaluation (p. 312). Academic Conferences International Limited.

Omwenga, K. O. N. J. Q., \& Iravo, M. (2015) Determinants of Effective Leadership in Banks: A Case Study of Diamond Trust Bank-Kenya.

Osir, E. O. (2016). Role of e-procurement adoption on procurement performance in state corporations in Kenya: A case of Kenya Utalii College. International Academic Journal of Procurement and Supply Chain Osir Management, 2 (1), 66-100

Republic of Kenya. 2007. "Kenya Vision 2030 - The Popular Version." http://vision2030.go.ke/inc/uploads/2018/05/Vision- 2030-Popular-Version.pdf

Sekaran. U \& Bougie, R (2016). Research methods for business: a skill-building approach, (6th Ed, Chichester), West Sussex, United Kingdom: John Wiley \& Sons

Shemi, A. P. (2012). Factors affecting e-commerce adoption in small and medium enterprises: An interpretive study of Botswana (Doctoral dissertation, University of Salford).

Smadi, Z. M. A., \& Ababneh, H. T. (2018). Toward Realizing Operational Excellence through e-Procurement Adoption a Resource Based View. Global Journal of Management and Business Research.

Wachinga, H. (2019). National innovation system factors, incentives, culture and institutional linkages in Kenyan ICT innovation firms (doctoral dissertation, school of business, university of Nairobi).

Wasike, Sagwa \& Sakwa (2018). Mediating Influence of Information Technology Infrastructure in the Relationship Between Supply Chain Process Integration Capabilities and Supply Chain Performance of Public Universities in Kenya European Journal of Business and Management www.iiste.org ISSN 2222-1905 (Paper) ISSN 2222-2839 (Online) Vol.10, No.29, 201868 